\title{
Analysis of Financial Performance Development Based on EVA Approach and Profitability Ratio at Barokah Village Unit Cooperative in Karya Mukti Village, Subdistrict Maro Sebo Ilir
}

\author{
Muryati ${ }^{1}$, Ahkmadi \\ Sekolah Tinggi Ilmu Ekonomi Graha Karya Muara Bulian Jambi ${ }^{1}$
}

\begin{abstract}
The development of financial position had a very important meaning for the company. The important factor to see development of the company was the financial element, because that can evaluate the capability of the company is correct or not. The purpose of this research was to know the development of the financial performance based on EVA approach and profitability ratio at Barokah Village Unit Cooperative in Karya Mukti Village, subdistrict Maro Sebo Ilir. The problem's formulation from this research was how is the development of the financial performance based on EVA approach and profitability ratio at Barokah Village Unit Cooperative in Karya Mukti Village, subdistrict Maro Sebo Ilir. The type of data used in this research was primary and secondary data from Barokah Village Unit Cooperative in Karya Mukti Village, subdistrict Maro Sebo Ilir. The method of this research was descriptive quantitative method and using EVA and profitability ratio analysis. The result of the research based on EVA approach and profitability ratio was financial performance at Barokah Village Unit Cooperative based on NOPAT/SHU Income, Invested Capital, WACC, Capital Charges and EVA was good. Financial performance based on ROI was not too good and based on ROE was good. Financial performance based on EVA approach have a good average value, but must be kept in order to get a better value. Financial performance based on profitability ratio especially ROI was not good, so it must be improved in order to get a good value.
\end{abstract}

Keywords : Financial performance, EVA and profitability ratio

\section{PENDAHULUAN}

Perkembangan posisi keuangan memiliki arti yang sangat penting bagi perusahaan. Untuk melihat sehat tidaknya suatu perusahaan tidak hanya dapat dilihat dari keadaaan fisiknya saja, misalnya dilihat dari gedung atau pembangunan. Faktor terpenting untuk dapat melihat perkembangan suatu perusahaan terletak dalam unsur keuangannya, karena dari unsur tersebut juga dapat mengevaluasi kebijakan yang ditempuh suatu perusahaan sudah tepat atau belum, mengingat sudah begitu kompleknya permasalahan yang dapat menyebabkan kebangkrutan dikarenakan banyaknya perusahaan yang akhirnya gulung tikar karena faktor keuangan yang tidak sehat. Dengan keadaan sekarang ini, dimana persaingan ketat dibidang perekonomian sudah mulai masuk kenegara Indonesia, maka jika seorang manajer perusahaan tidak memperhatikan faktor kesehatan dalam perusahaannya, mungkin saja akan terjadi kebangkrutan seperti yang telah dikemukakan sebelumnya.

Analisa keuangan pada dasarnya ingin melihat prospek dan risiko perusahaan. Prospek itu bisa dilihat dari tingkat keuntungan (profitabilitas) dan risiko bisa dilihat dari kemungkinan perusahaan mengalami kesulitan keuangan atau kebangkrutan.

Untuk menghindari kebangkrutan tesebut maka seorang manajer perusahaan sangat penting untuk selalu berusaha agar perusahaannya dapat terus berjalan atau dengan kata lain manajer tersebut dapat menjaga kelangsungan hidup perusahaannya yang ditempuh dengan cara selalu memperhatikan dan mengadakan evaluasi terhadap perkembangan 
perusahaannya dari waktu ke waktu. Seorang manajer harus dapat memahami kondisi keuangan tersebut yang sangat mempengaruhi kelangsungan hidup perusahaannya secara keseluruhan.

Salah satu alat yang dipakai untuk mengetahui kondisi kinerja keuangan, dalam hal ini tingkat kesehatan suatu perusahaan adalah berwujud laporan keuangan yang disusun pada setiap akhir periode yang berisi pertanggungjawaban dalam bidang keuangan atas berjalannya suatu usaha.

Untuk mengukur tingkat kesehatan keuangan atau kinerja keuangan perusahaan dapat digunakan alat analisa yang disebut analisa rasio keuangan. Untuk melakukan analisa rasio keuangan, diperlukan perhitungan rasio-rasio yang mencerminkan aspek-aspek tertentu. Rasio keuangan mungkin duhitung berdasarkan atas angka-angka yang ada dalam neraca saja, dalam laporan laba rugi saja, atau pada neraca dan laporan laba rugi.

Analisis laporan keuangan digunakan untuk menentukan dan mengukur hubungan antara pos-pos yang ada dalam laporan, sehingga dapat diketahui perubahan-perubahan dari masing-masing pos tersebut bila diperbandingkan dengan laporan dari beberapa periode untuk satu perusahaan tertentu.

Kegunaan dari laporan keuangan itu sendiri yang data akuntansi yang diambil dari laporan laba rugi dan neraca berasal dari elemen laporan keuangan. Dengan adanya data tersebut dapat dianalisa melalui analisa EVA dan rasio profitabilitas. Masing-masing analisa tersebut akan memberikan informasi tentang kinerja keuangan suatu perusahaan.

EVA bagi manajemen digunakan untuk memilih investasi yang memaksimumkan tingkat pengembalian dan meminimumkan tingkat biaya modal sehingga perusahaan dapat dimaksimumkan. Tingkat rasio profitabilitas menunjukkan kemampuan perusahaan untuk menghasilkan laba.
Laporan keuangan merupakan alat yang sangat penting untuk memperoleh informasi sehubungan dengan posisi keuangan dan hasil- hasil yang telah dicapai oleh perusahaan yang bersangkutan. Laporan keuangan dalam banyak hal mampu menyajikan komponenkomponen yang penting dalam keadaan keuangan perusahaan, sehingga dapat digunakan sebagai alat pertimbangan dalam pengambilan keputusan. Laporan keuangan dapat memberikan informasi sehubungan dengan kondisi keuangan dan hasil yang dicapai oleh perusahaan dalam periode tertentu.

Koperasi merupakan badan usaha yang beranggotakan orang seorang atau badan-badan hukum koperasi dengan melandaskan kegiatannya berdasarkan prinsip koperasi sekaligus sebagai gerakan ekonomi rakyat yang berdasarkan atas azas kekeluargaan. Dimasa sekarang ini sudah sangat sulit untuk menemukan koperasi yang masih sehat dan berjalan dengan baik, sebuah koperasi harus mampu menyesuaikan dengan perkembangan ekonomi yang terjadi pada saat sekarang ini, baik itu keadaan yang menguntungkan maupun yang merugikan koperasi. Untuk terus bertahan sebuah koperasi harus terus mengoptimalkan fungsi operasionalnya yang meliputi fungsi keuangan, fungsi personalia dan fungsi pemasarannya. Sehingga dapat tercapai efesiensi dan efektifitas koperasi tersebut. Untuk mencapai kondisi yang menguntungkan pada setiap fungsi, setiap koperasi dituntut untuk menjalankan usahanya dengan pengelolaan yang baik sehingga dapat mendorong koperasi dalam mencapai tujuannya yaitu mengembangkan koperasi dan meningkatkan kesejahteraan ekonomi para anggotanya.

Berdasarkan uraian dari latar belakang penelitian, maka pokok permasalahan dalam penelitian ini adalah: Bagaimana perkembangan kinerja keuangan berdasarkan Pendekatan Economic Value Added dan pendekatan 
profitabilitas pada Koperasi Unit Desa (KUD) Barokah Desa Karya Mukti Kecamatan Maro Sebo Ilir.

Tujuan dari penelitian ini adalah: 1) Untuk mengetahui dan menganalisis perkembangan kinerja keuangan berdasarkan Pendekatan Economic Value Added pada Koperasi Unit Desa (KUD) Barokah Desa Karya Mukti Kecamatan Maro Sebo Ilir; 2) Untuk mengetahui dan menganalisis perkembangan kinerja keuangan berdasarkan Pendekatan Rasio Profitabilitas pada Koperasi Unit Desa (KUD) Barokah Desa Karya Mukti Kecamatan Maro Sebo Ilir.

\section{Kerangka Pemikiran}

Pendekatan EVA (Economic Value Added) merupakan pendekatan baru dalam menilai kinerja perusahaan dengan memperhatikan secara adil ekspektasi penyandang dana. EVA merupakan hasil pengurangan total biaya modal terhadap laba operasi setelah pajak. Penilaian kinerja dengan menggunakan pendekatan EVA menyebabkan perhatian manajemen sesuai dengan kepentingan pemegang saham. EVA digunakan untuk memilih investasi yang memaksimumkan tingkat pengembalian dan meminimumkan tingkat biaya modal sehingga perusahaan dapat dimaksimumkan. Untuk menilai atau mengetahui pendekatan EVA dari suatu koperasi dalam hal ini digunakan NOPAT/SHU Bersih, Invested Capital, WACC, Capital Charges, Economic Value Added (EVA).

Profitabilitas merupakan kemampuan mendapatkan laba melalui semua kemampuan dan sumber yang ada seperti kegiatan penjualan, kas, modal, jumlah karyawan, dan sebagainya. Rasio ini mengukur efektif manajemen secara keseluruhan yang ditujukan oleh besar kecilnya tingkat keuntungan yang diperoleh dalam hubungannya dengan penjualan maupun investasi. Semakin baik rasio ini maka semakin baik menggambarkan kemampuan tingginya perolehan keuntungan perusahaan. Untuk menilai atau mengetahui tingkat profitabilitas dari suatu koperasi dalam hal ini digunakan dua rasio yaitu return on investment dan return on equity.

Koperasi yang mampu memenuhi kewajiban keuangannya tepat pada waktunya, maka posisi keuangan perusahaan tersebut dalam keadaan baik atau dapat dikatakan "liquid", sedangkan koperasi yang tidak dapat memenuhi kewajiban keuangannya pada saat ditagih maka tersebut dalam keadaaan "Illiquid". Posisi keuangan yang liquid bagi suatu perusahaan sangat penting untuk memberikan kepercayaan bagi para kreditor sebagai pihak yang akan memberikan pinjaman.

Rasio dapat dipahami sebagai hasil yang diperoleh antara satu jumlah dengan jumlah yang lainnya. Suatu perusahaan sangat membutuhkan skala atau pengukuran untuk melihat kinerja perusahaan tersebut dalam suatu periode tertentu. Oleh karena itu perusahaan tersebut membutuhkan laporan neraca dan laba rugi untuk melihat kinerja perusahaannya.

\section{Landasan Teori}

Manajemen keuangan menurut Kamaludin (2011 : 1) adalah upaya dan kegiatan dalam rangka meningkatkan nilai perusahaan, untuk mendapatkan dana dengan cara yang paling menguntungkan serta mengalokasikan dana secra efisien dalam perusahaan sebagai sarana untuk mencapai sasaran bagi kekayaan pemegang saham.

Menurut pendapat James Van Horne, bahwa pengertian manajemen keuangan adalah semua kegiatan atau aktivitas yang berhubungan langsung dengan perolehan pendanaan serta pengelolaan aset (aktiva) dengan tujuan yang menyeluruh.

Kinerja keuangan merupakan hasil nyata yang dicapai suatu badan usaha dalam suatu periode tertentu yang dapat mencerminkan tingkat kesehatan keuangan badan usaha tertentu dan dipergunakan 
untuk menunjukkan dicapainya hasil yang positif.

Kinerja keuangan suatu perusahaan dapat dilihat dan diukur dengan cara menganalisa laporan keuangan yang tersedia. Melalui analisa laporan keuangan, identitas dan perkembangan finansial perusahaan serta hasil-hasil yang telah dicapai perusahaan dapat diketahui, baik di waktu lampau maupun di waktu yang sedang berjalan sehubungan dengan pemilihan strategi perusahaan yang akan diterapkan.

Dari segi manajemen keuangan, perusahaan dikatakan mempunyai kinerja yang baik atau dapat di ukur dengan :

- Kemampuan perusahaan untuk memenuhi kewajiban (Hutang) yang akan jatuh tempo (Liquidity)

- Kemampuan perusahaan untuk menyusun struktur pendanaan, yaitu perbandingan antara utang dan modak (Leverage)

- Kemampuan perusahaan memperoleh keuntungan (Profitability)

- Kemampuan perusahaan untuk berkembang (Growth) dan

- Kemampuan perusahaan untuk mengelola aset secara maksimal (Activity)

Menurut Fahmi (2011 : 2) analisis kinerja keuangan adalah suatu analisis yang dilakukan untuk melihat sejauh mana suatu perusahaan telah melaksanakan dengan menggunakan aturan-aturan pelaksanaan keuangan secara baik dan benar.

EVA merupakan pendekatan baru dalam menilai kinerja perusahaan dengan memperhatikan secara adil ekspektasi penyandang dana. EVA adalah nilai tambah ekonomis. EVA merupakan salah satu alat pengukuran kinerja perusahaan yang dipopulerkan oleh G. Bennet Stewart dan Joel M. Stern pada tahun 1991 yang merupakan analisis keuangan dari perusahaan konsultan Stren Stewart and Co. EVA didasarkan pada gagasan keuntungan ekonomis sebagai residual income yang menyatakan bahwa kekayaan dalam suatu perusahaan hanya diciptakan pada saat perusahaan mampu menutup biaya operasi dan biaya modal.

Dalam perhitungannya, EVA adalah laba tertinggal setelah dikurangi dengan biaya modal (cost capital) yang diinvestasikan untuk menghasilkan laba tersebut, sehingga dapat menjadi suatu tolak ukur kinerja keuangan berbasis nilai. EVA juga menggambarkan jumlah absolut dari nilai pemegang saham yang diciptakan atau dirusak pada suatu periode tertentu, biasanya setahun. EVA yang positif menunjukkan penciptaan nilai, sedangkan EVA yang negatif menunjukkan penghancuran nilai (Tunggal 2010).

Menurut Young dan O’Byrne (2010), EVA sebagai penengah antara pengukuran nilai dan kinerja perusahaan. EVA mengukur pertambahan nilai yang dihasilkan oleh manajemen berkaitan dengan usaha manajemen untuk meningkatkan kemakmuran pemegang sahamnya.

Penilaian kinerja dengan menggunakan pendekatan EVA menyebabkan perhatian manajemen sesuai dengan kepentingan pemegang saham. Dimana pemegang saham didalam menginvestasikan dananya ingin mendapatkan return saham yang tinggi. Sedangkan bagi manajemen EVA digunakan untuk memilih investasi yang memaksimumkan tingkat pengembalian dan meminimumkan tingkat biaya modal sehingga perusahaan dapat dimaksimumkan.

Pada dasarnya, EVA mengukur nilai tambah dalam suatu periode tertentu. Nilai tambah ini tercipta bila perusahaan memperoleh keuntungan (profit) diatas cost of capital perusahaan. Secara matematis, EVA dihitung dari laba setelah pajak dikurangi dengan cost of capital tahunan. Jika EVA positif, menunjukkan perusahaan telah menciptakan kekayaan.

Menurut Bambang (2010 : 35) profitabilitas suatu perusahaan menunjukkan perbandingan antara laba 
dengan aktiva atau modal yang menghasilkan laba tersebut. Dengan kata lain rentabilitas adalah kemampuan suatu perusahaan untuk menghasilkan laba selama periode tertentu. Menurut Kasmir (2012 : 196), rasio profitabilitas adalah rasio untuk menilai kemampuan perusahaan dalam mencari keuntungan.

Rasio ini mengukur efektifitas manajemen secara keseluruhan yang ditujukan oleh besar kecilnya tingkat keuntungan yang diperoleh dalam hubungannya dengan penjualan maupun investasi. Semakin baik rasio profitabilitas maka semakin baik menggambarkan kemampuan tingginya perolehan keuntungan perusahaan.

\section{METODE PENELITIAN}

Untuk mengetahui permasalahan yang dikemukakan dalam penelitian ini maka digunakan alat analisis sebagai berikut:

\section{Pendekatan EVA (Economic Value Added)}

1. NOPAT (Net Operating After Tax)/SHU Bersih

Adapun rumusan NOPAT/SHU Bersih sebagai berikut:

NOPAT/SHU Bersih = SHU Kotor Pajak

Pajak yang digunakan adalah pajak jasa giro bank.

2. Invested Capital

Adapun rumusan Invested Capital sebagai berikut:

Invested Capital $=$ (Total Hutang + Ekuitas) - Hutang Jangka Pendek

3. WACC (Weighted Average Cost of Capital)

Adapun rumusan WACC sebagai berikut:

WACC $=[(\mathrm{D} \times \mathrm{rd})(1-\operatorname{tax})+(\mathrm{E} \times$ re)]

Dimana :

$$
\begin{aligned}
& \text { Tingkat Modal }(\mathrm{D})=\frac{\text { Total Hutang }}{\text { Total Hutang dan Ekuitas }} \times 100 \% \\
& \text { Cost of Debt }(r d)=\frac{\text { Beban Bunga }}{\text { Total Hutang }} \times 100 \% \\
& \text { Tingkat Modal / Ekuitas }(\mathrm{E})=\frac{\text { Total Ekuitas }}{\text { Total Hutang dan Ekuitas }} \times 100 \% \\
& \text { Cost of Equity }(r e)=\frac{\text { SHU bersih setelah pajak }}{\text { Total Ekuitas }} \times 100 \% \\
& \text { Tingkat Pajak }(\text { Tax })= \\
& \text { SHU Bersih sebelum pajak }
\end{aligned}
$$

4. Capital Charges

Adapun rumusan Capital Charges sebagai berikut:

Capital Charges = WACC $\mathrm{x}$ Invested Capital

5. EVA (Economic Value Added)
Adapun rumusan EVA sebagai berikut: EVA $=$ NOPAT/SHU Bersih Capital charges

\section{Rasio Profitabilitas}

1. Return On Investment (ROI) 
Adapun rumusan Return On Investment sebagai berikut :

EAIT

Return On Investment $=\frac{}{\text { Total Aktiva }} \times 100 \%$

Keterangan :

- EAIT = Laba Sesudah Bunga dan Pajak

2. Return On Equity (ROE)

Adapun rumus Return On Equity sebagai berikut : EAIT

Return On Equity $=\underset{\text { Total Ekuitas }}{\text { x } 100 \%}$

\section{HASIL DAN PEMBAHASAN \\ Pendekatan EVA (Economic Value Added)}

Untuk menilai atau mengetahui pendekatan EVA dari koperasi dalam hal ini digunakan NOPAT/SHU Bersih, Invested Capital, WACC, Capital Charges, Economic Value Added (EVA).

Perhitungan NOPAT /SHU Bersih.

Tabel: 1 Hasil perhitungan NOPAT/SHU Bersih KUD Barokah Kecamatan Maro Sebo Ilir Tahun 2012-2016

\begin{tabular}{|c|c|c|c|c|}
\hline Tahun & \begin{tabular}{|c|} 
SHU Kotor \\
(Rp) \\
\end{tabular} & $\begin{array}{l}\text { Pajak } \\
\text { (Rp) }\end{array}$ & $\begin{array}{c}\text { NOPAT/SHU } \\
\text { Bersih } \\
(\text { Rp) }\end{array}$ & $\begin{array}{c}\text { Prkmbngn } \\
(\%)\end{array}$ \\
\hline 2012 & 71.484 .882 & 2.474 .443 & 69.010 .439 & - \\
\hline 2013 & 116.394 .846 & 170.944 & 116.223 .902 & 68 \\
\hline 2014 & 221.853 .375 & 3.982 .873 & 217.870 .502 & 87 \\
\hline 2015 & 413.608 .500 & 1.799 .057 & 411.809 .443 & 89 \\
\hline 2016 & 48.128 .230 & 597.498 & 47.530 .732 & -88 \\
\hline \multicolumn{3}{|c|}{ Rata-rata } & 172.489 .004 & 31,2 \\
\hline
\end{tabular}

Sumber : Data diolah

Dari tabel diatas dapat dilihat bahwa nilai NOPAT/SHU Bersih KUD Barokah tahun 2012 sampai 2016 adalah sebagai berikut:

Pada tahun 2012 NOPAT/SHU Bersih KUD diperoleh hasil dari perbandingan antara SHU Kotor sebesar Rp.71.484.882,- dengan pajak sebesar Rp.2.474.443,- adalah sebesar Rp.69.010.439,- hal ini berarti NOPAT/SHU Bersih yang dihasilkan adalah sebesar Rp.69.010.439,-. Kondisi ini sudah memenuhi standar yang telah ditetapkan.

Pada tahun 2013 NOPAT/SHU Bersih KUD diperoleh hasil dari perbandingan antara SHU kotor sebesar Rp.116.394.846,- dengan pajak sebesar Rp.170.944,- adalah sebesar Rp.116.223.902,- hal ini berarti NOPAT/SHU Bersih yang dihasilkan adalah sebesar Rp. 116.223.902,-. Kondisi peningkatan ini dipengaruhi oleh meningkatnya SHU kotor serta menurunnya pajak.

Pada tahun 2014 NOPAT/SHU Bersih KUD diperoleh hasil dari perbandingan antara SHU kotor sebesar Rp.221.853.375,- dengan pajak sebesar Rp.3.982.873,- adalah sebesar Rp. 217.870.502,- hal ini berarti NOPAT/SHU Bersih yang dihasilkan adalah sebesar Rp. 217.870.502,-. Kondisi peningkatan ini dipengaruhi oleh meningkatnya SHU kotor serta meningkatnya pajak.

Pada tahun 2015 NOPAT/SHU Bersih KUD diperoleh hasil dari perbandingan antara SHU kotor sebesar Rp.413.608.500,- dengan pajak sebesar Rp.1.799.057,- adalah sebesar Rp. 411.809.443,- hal ini berarti NOPAT/SHU Bersih yang dihasilkan adalah sebesar Rp. 411.809.443,-. Kondisi peningkatan ini dipengaruhi oleh meningkatnya SHU kotor serta menurunnya pajak.

Pada tahun 2016 NOPAT/SHU Bersih KUD diperoleh hasil dari perbandingan antara SHU kotor sebesar 
Rp.48.128.230,- dengan pajak sebesar Rp.597.498,- adalah sebesar Rp. 47.530.732,- hal ini berarti NOPAT/SHU Bersih yang dihasilkan adalah sebesar Rp. 47.530.732,-. Kondisi penurunan ini dipengaruhi oleh menurunnya SHU kotor serta meningkatnya pajak.

Melihat perkembangan berdasarkan hasil analisis rata-rata NOPAT/SHU bersih dari tahun 2012 sampai 2016 sebesar Rp.172.489.004,- artinya Nopat/SHU bersih rata-rata sebesar Rp.172.489.004 > 0 sudah memenuhi standar koperasi yang ditetapkan.

\section{Modal yang Diinvestasikan (Invested Capital)}

Invested Capital atau modal yang diinvestasikan adalah total hutang ditambah ekuitas dikurangi hutang jangka pendek. Berikut adalah hasil dari perhitungan Invested Capital :

Tabel : 2 Hasil perhitungan Invested Capital KUD Barokah Kecamatan Maro Sebo Ilir Tahun 2012-2016

\begin{tabular}{|c|c|c|c|c|c|}
\hline \multirow[t]{2}{*}{ Tahun } & Total Hutang & Ekuitas & $\begin{array}{l}\text { Htg Jangka } \\
\text { Pendek }\end{array}$ & $\begin{array}{l}\text { Invested } \\
\text { Capital }\end{array}$ & prkmbangan \\
\hline & (Rp) & (Rp) & (Rp) & (Rp) & $(\%)$ \\
\hline 2012 & 1.332.078.576 & 394.971 .690 & 1.332.078.576 & 394.971 .690 & - \\
\hline 2013 & \begin{tabular}{|l|l|}
1.057 .732 .751 \\
\end{tabular} & 496.337 .762 & \begin{tabular}{|l}
1.057 .732 .751 \\
\end{tabular} & 496.337 .762 & 26 \\
\hline 2014 & \begin{tabular}{|l|l|}
4.528 .532 .082 \\
\end{tabular} & 697.765 .338 & \begin{tabular}{|l}
4.528 .532 .082 \\
\end{tabular} & 697.765 .338 & 41 \\
\hline 2015 & 1.750 .758 .466 & 1.019.971.904 & 1.750 .758 .466 & 1.019.971.904 & 46 \\
\hline 2016 & 2.977.010.804 & 817.785 .819 & 2.977.010.804 & 817.785 .819 & -20 \\
\hline \multicolumn{4}{|c|}{ Rata-rata } & 685.366 .503 & 18,6 \\
\hline
\end{tabular}

Sumber : Data diolah

Pada tahun 2012 Invested Capital KUD diperoleh hasil dari perbandingan antara total hutang sebesar Rp.1.332.078.576,- ditambah ekuitas sebesar Rp.394.971.690,- dengan hutang jangka pendek sebesar Rp.1.332.078.576,adalah sebesar Rp.394.971.690,-. Hal ini berarti ekuitas yang digunakan dalam usaha koperasi akan menghasilkan laba sebesar Rp.394.971.690,-.

Tahun 2013 Invested Capital KUD diperoleh hasil dari perbandingan antara total hutang sebesar Rp.1.057.732.751,- ditambah ekuitas sebesar Rp.496.337.762,dengan hutang jangka pendek sebesar Rp. 1.057.732.751,- adalah sebesar Rp.496.337.762,-. Kondisi ini mengalami peningkatan yang dipengaruhi oleh menurunnya total hutang yang berupa hutang usaha dan hutang biaya YMHD, meningkatnya ekuitas yang berupa simpanan wajib dan cadangan koperasi dan menurunnya hutang jangka pendek berupa hutang usaha dan hutang biaya YMHD.

Pada tahun 2014 Invested Capital KUD diperoleh hasil dari perbandingan antara total hutang sebesar Rp.4.528.532.082,- ditambah ekuitas sebesar Rp.697.765.338,- dengan hutang jangka pendek sebesar Rp. 4.528.532.082,adalah sebesar Rp.697.765.338,-. Kondisi ini mengalami peningkatan yang dipengaruhi oleh meningkatnya total hutang yang berupa hutang usaha dan dana jalan poros, meningkatnya ekuitas yang berupa simpanan wajib dan cadangan koperasi dan meningkatnya hutang jangka pendek berupa hutang usaha dan dana jalan poros.

Pada tahun 2015 Invested Capital KUD diperoleh hasil dari perbandingan antara total hutang sebesar Rp.1.750.758.466,- ditambah ekuitas sebesar Rp.1.019.971.904,- dengan hutang jangka pendek sebesar Rp. 1.750.758.466,adalah sebesar Rp. 1.019.971.904,-Kondisi ini mengalami peningkatan yang dipengaruhi oleh menurunnya total hutang yang berupa hutang usaha, hutang biaya YMHD dan dana jalan poros, meningkatnya ekuitas yang berupa simpanan wajib dan cadangan koperasi dan menurunnya hutang jangka pendek berupa hutang usaha, hutang biaya YMHD dan dana jalan poros.

Pada tahun 2016 Invested Capital KUD diperoleh hasil dari perbandingan antara total hutang sebesar Rp.2.977.010.804,- ditambah ekuitas sebesar Rp.817.785.819,- dengan hutang jangka pendek sebesar Rp. 2.977.010.804,adalah sebesar Rp.817.785.819,-. Kondisi 
ini mengalami peningkatan yang dipengaruhi oleh meningkatnya total hutang yang berupa hutang usaha, menurunnya ekuitas dan meningkatnya hutang jangka pendek berupa hutang usaha.

Melihat perkembangan berdasarkan hasil analisis rata-rata nilai Invested
Capital KUD Barokah dari tahun 2012 sampai 2016 sebesar Rp.685.366.503 artinya Invested Capital rata-rata sebesar Rp.685.366.503 > 0 sudah memenuhi standar koperasi yang ditetapkan.

Biaya Modal Rata Tertimbang (WACC)

Tabel: 3. Hasil perhitungan WACC KUD Barokah Kecamatan Maro Sebo Ilir Tahun 20122016

\begin{tabular}{|c|c|c|c|c|c|c|c|c|}
\hline Tahun & D & rd & 1 & Tax & $\mathbf{E}$ & re & WACC & Perkmbngn (\%) \\
\hline 2012 & $\mathbf{0 , 7 7 1 3}$ & 0,0765 & 1 & 0,0346 & 0,2287 & 0,1747 & 0,08 & - \\
\hline 2013 & 0,6806 & 0,0963 & 1 & 0,0015 & 0,3194 & 0,2342 & 0,13 & 63 \\
\hline 2014 & 0,8665 & 0,0225 & 1 & 0,0180 & 0,1335 & 0,3122 & 0,05 & -62 \\
\hline 2015 & 0,6319 & $\mathbf{0 , 0 5 8 2}$ & 1 & 0,0043 & 0,3681 & 0,4037 & $\mathbf{0 , 1 7}$ & 240 \\
\hline 2016 & $\mathbf{0 , 7 8 4 5}$ & 0,0342 & 1 & 0,0124 & 0,2155 & $\mathbf{0 , 0 5 8 1}$ & $\mathbf{0 , 0 3}$ & -82 \\
\hline \multicolumn{7}{|c|}{ Rata-rata } & 0,09 & 31,8 \\
\hline
\end{tabular}

Sumber : Data diolah

Pada tahun 2012 WACC KUD yang diperoleh dari hasil perbandingan antara Tingkat Modal (D) sebesar Rp.0,7713,Cost of Debt (rd) sebesar Rp.0,0765,Tingkat Pajak (Tax) sebesar Rp.0,0346,Ekuitas (E) sebesar Rp.0,2287,- dan Cost of Equity (re) sebesar Rp.0,1747,-- adalah sebesar Rp.0,08,- hal ini berarti komponen modal sebesar Rp.0,08 > 0. Kondisi ini sudah memenuhi standar koperasi yang ditetapkan.

Pada tahun 2013 WACC KUD yang diperoleh dari hasil perbandingan antara Tingkat Modal (D) sebesar Rp.0,6806,Cost of Debt (rd) sebesar Rp.0,0963,Tingkat Pajak (Tax) sebesar Rp.0,0015,Ekuitas (E) sebesar Rp.0,3194,- dan Cost of Equity (re) sebesar Rp.0,2342,- adalah sebesar Rp.0,13,- hal ini berarti komponen modal sebesar Rp.0,13 > 0. Kondisi ini mengalami peningkatan disebabkan oleh menurunnya Tingkat modal, meningkatnya cost of debt, menurunnya tax, meningkatnya ekuitas serta meningkatnya cost of equity.

Pada tahun 2014 WACC KUD yang diperoleh dari hasil perbandingan antara Tingkat Modal (D) sebesar Rp.0,8665,Cost of Debt (rd) sebesar Rp.0,0225,-
Tingkat Pajak (Tax) sebesar Rp.0,0180,Ekuitas (E) sebesar Rp.0,1335,- dan Cost of Equity (re) sebesar Rp.0,3122,- adalah sebesar Rp.0,05,- hal ini berarti komponen modal sebesar Rp.0,05,- > 0. Kondisi ini mengalami penurunan disebabkan oleh meningkatnya Tingkat modal, menurunnya cost of debt, meningkatnya tax dan ekuitas serta meningkatnya cost of equity.

Pada tahun 2015 WACC KUD yang diperoleh dari hasil perbandingan antara Tingkat Modal (D) sebesar Rp.0,6319,Cost of Debt (rd) sebesar Rp.0,0582,Tingkat Pajak (Tax) sebesar Rp.0,0043,Ekuitas (E) sebesar Rp.0,3681,- dan Cost of Equity (re) sebesar Rp.0,4037,- adalah sebesar Rp.0,17,- hal ini berarti komponen modal sebesar Rp.0,17 > 0. Kondisi ini mengalami peningkatan disebabkan oleh menurunnya Tingkat modal, meningkatnya cost of debt, menurunnya tax, meningkatnya ekuitas serta meningkatnya cost of equity.

Pada tahun 2016 WACC KUD yang diperoleh dari hasil perbandingan antara Tingkat Modal (D) sebesar Rp.0,7845,Cost of Debt (rd) sebesar Rp.0,0342,Tingkat Pajak (Tax) sebesar Rp.0,0124,Ekuitas (E) sebesar Rp.0,2155,- dan Cost 
of Equity (re) sebesar Rp.0,0581,- adalah sebesar Rp.0,03,- hal ini berarti komponen modal sebesar Rp.0,03 > 0. Kondisi ini mengalami penurunan disebabkan oleh meningkatnya Tingkat modal, menurunnya cost of debt, meningkatnya tax, menurunnya ekuitas serta menurunnya cost of equity.

Melihat perkembangan berdasarkan hasil analisis rata-rata WACC dari tahun 2012 sampai 2016 KUD Barokah adalah sebesar Rp.0,09,- artinya biaya modal rataan tertimbang rata-rata sebesar Rp.0,09 $>0$ sudah memenuhi standar koperasi yang ditetapkan.

\section{Biaya Modal (Capital Charges)}

Berikut adalah hasil dari perhitungan Capital Charges :

Tabel : 4. Hasil perhitungan Capital Charges KUD Barokah Kecamatan Maro Sebo Ilir Tahun 2012-2016

\begin{tabular}{|c|c|c|c|c|}
\hline Tahun & WACC & $\begin{array}{c}\text { Invested } \\
\text { Capital }\end{array}$ & Capital Charges & Perkembangan \\
\hline & (Rp) & (Rp) & (Rp) & $(\%)$ \\
\hline 2012 & 0,08 & 394.971 .690 & 31.597 .735 & - \\
\hline 2013 & 0,13 & 496.337 .762 & 64.523 .909 & 104 \\
\hline 2014 & 0,05 & 697.765 .338 & 34.888 .267 & -46 \\
\hline 2015 & 0,17 & 1.019 .971 .904 & 173.395 .224 & 397 \\
\hline 2016 & 0,03 & 817.785 .819 & 24.533 .575 & -94 \\
\hline \multicolumn{3}{|c|}{ ata- } & 65.787 .742 & 72,2 \\
\hline
\end{tabular}

Sumber : Data diolah

Pada tahun 2012 Capital Charges KUD diperoleh hasil dari perbandingan antara WACC sebesar Rp.0,08,- dengan Invested Capital sebesar Rp.394.971.690,adalah sebesar Rp.31.597.735,-. Hal ini berarti Capital Charges yang dihasilkan adalah sebesar Rp.31.597.735,--

Pada tahun 2013 Capital Charges KUD diperoleh hasil dari perbandingan antara WACC sebesar Rp.0,13,- dengan Invested Capital sebesar Rp.496.337.762,adalah sebesar Rp.64.523.909,--. Hal ini berarti Capital Charges yang dihasilkan adalah sebesar Rp.64.523.909,-. Kondisi ini mengalami peningkatan yang dipengaruhi oleh meningkatnya WACC dan meningkatnya Invested Capital.
Pada tahun 2014 Capital Charges KUD diperoleh hasil dari perbandingan antara WACC sebesar Rp.0,05,- dengan Invested Capital sebesar Rp.496.337.762,adalah sebesar Rp.34.888.267,-. Hal ini berarti Capital Charges yang yang dihasilkan adalah sebesar Rp.34.888.267,-Kondisi ini mengalami penurunan yang dipengaruhi oleh menurunnya WACC dan meningkatnya Invested Capital.

Pada tahun 2015 Capital Charges KUD diperoleh hasil dari perbandingan antara WACC sebesar Rp.0,17,- dengan Invested Capital sebesar Rp.1.019.971.904,- adalah sebesar Rp.173.395.224,-. Hal ini berarti Capital Charges yang yang dihasilkan adalah sebesar Rp.173.395.224,-. Kondisi ini mengalami peningkatan yang dipengaruhi oleh meningkatnya WACC dan meningkatnya Invested Capital.

Pada tahun 2016 Capital Charges KUD diperoleh hasil dari perbandingan antara WACC sebesar Rp.0,03,- dengan Invested Capital sebesar Rp.817.785.819,adalah sebesar Rp.24.533.575,-. Hal ini berarti Capital Charges yang yang dihasilkan adalah sebesar Rp.24.533.575,-. Kondisi ini mengalami penurunan yang dipengaruhi oleh menurunnya WACC dan menurunnya Invested Capital.

Melihat perkembangan berdasarkan hasil analisis rata-rata nilai Capital Charges KUD Barokah dari tahun 2012 sampai 2016 sebesar Rp.65.787.742,artinya Capital Charges rata-rata sebesar Rp.65.787.742 > 0 sudah memenuhi standar koperasi yang ditetapkan.

\section{EVA (Economic Value Added) \\ Berikut adalah hasil dari perhitungan} EVA:

Tabel : 5. Hasil perhitungan EVA KUD Barokah Kecamatan Maro Sebo Ilir Tahun 2012-2016 


\begin{tabular}{|c|c|c|c|c|}
\hline \multirow[t]{2}{*}{ Tahun } & $\begin{array}{c}\text { NOPAT/SHU } \\
\text { Bersih }\end{array}$ & $\begin{array}{l}\text { Capital } \\
\text { Charges }\end{array}$ & EVA & perkembangan \\
\hline & (Rp) & (Rp) & (Rp) & $(\%)$ \\
\hline 2012 & 69.010 .439 & 31.597 .735 & 37.412 .704 & - \\
\hline 2013 & 116.223 .902 & 64.523 .909 & 51.699 .993 & 38 \\
\hline 2014 & 217.870 .502 & 34.888 .267 & 182.982 .235 & 254 \\
\hline 2015 & 411.809 .443 & 173.395 .224 & 238.414 .219 & 30 \\
\hline 2016 & 47.530 .732 & 24.533 .575 & 22.997 .157 & -90 \\
\hline \multicolumn{3}{|c|}{ Rata-rata } & 106.701.262 & 46,4 \\
\hline
\end{tabular}

Sumber : Data diolah

Pada tahun 2012 EVA KUD diperoleh hasil dari perbandingan antara NOPAT/SHU Bersih sebesar Rp.69.010.439,- dengan Capital Charges sebesar Rp.31.597.735,- adalah sebesar Rp.37.412.704,-. Hal ini berarti EVA yang dihasilkan adalah sebesar Rp.37.412.704,-

Tahun 2013 EVA KUD diperoleh hasil dari perbandingan antara NOPAT/SHU Bersih sebesar Rp.116.223.902,- dengan Capital Charges sebesar Rp.64.523.909,- adalah sebesar Rp.51.699.993,-. Kondisi ini mengalami peningkatan yang dipengaruhi oleh meningkatnya NOPAT/SHU Bersih dan meningkatnya Capital Charges.

Pada tahun 2014 EVA KUD diperoleh hasil dari perbandingan antara NOPAT/SHU Bersih sebesar Rp.217.870.502,- dengan Capital Charges sebesar Rp.34.888.267,- adalah sebesar Rp.182.982.235,-. Kondisi ini mengalami peningkatan yang dipengaruhi oleh meningkatnya NOPAT/SHU Bersih dan menurunnya Capital Charges.

Pada tahun 2015 EVA KUD diperoleh hasil dari perbandingan antara NOPAT/SHU Bersih sebesar Rp.411.809.443,-- dengan Capital Charges sebesar Rp.173.395.224,- adalah sebesar Rp.238.414.219,-. Kondisi ini mengalami peningkatan yang dipengaruhi oleh meningkatnya NOPAT/SHU Bersih dan meningkatnya Capital Charges.

Pada tahun 2016 EVA KUD diperoleh hasil dari perbandingan antara NOPAT/SHU Bersih sebesar Rp.47.530.732,- dengan Capital Charges sebesar Rp.24.533.575,- adalah sebesar
Rp.22.997.157,-. Kondisi ini mengalami penurunan yang dipengaruhi oleh menurunnya NOPAT/SHU Bersih dan menurunnya Capital Charges.

Melihat perkembangan berdasarkan hasil analisis rata-rata nilai EVA KUD Barokah dari tahun 2012 sampai 2016 sebesar Rp.106.701.262,- artinya EVA rata-rata sebesar Rp.106.701.262 > 0 sudah memenuhi standar koperasi yang ditetapkan.

\section{Pendekatan Rasio Profitabilitas}

Penilaian profitabilitas menggunakan dua cara, yaitu Return On Invesment /ROI dan Return On Equity /ROE.

\section{Return On Invesment /ROI}

Return On Invesment/ROI merupakan kemampuan untuk menghasilkan laba dari keseluruhan modal, baik modal asing maupun modal sendiri, yang digunakan untuk menghasilkan SHU. Tabel: 6. Hasil perhitungan rasio Return On Invesment /ROI KUD Barokah Kecamatan Maro Sebo Ilir Tahun 2012 2016.

\begin{tabular}{|c|c|c|c|c|}
\hline Tahun & \begin{tabular}{|c} 
Laba Setelah \\
Pajak
\end{tabular} & Total Aktiva & ROI & Perkembangan \\
\hline & (Rp) & (Rp) & $(\%)$ & $(\%)$ \\
\hline 2012 & 69.010 .440 & 1.727 .050 .266 & 4,00 & - \\
\hline 2013 & 116.223 .902 & 1.554 .070 .512 & 7,48 & 87 \\
\hline 2014 & 217.870 .502 & 5.226.297.419 & 4,17 & -44 \\
\hline 2015 & 411.809 .443 & 2.770 .730 .370 & 14,86 & 256 \\
\hline 2016 & 47.530 .732 & 3.794 .796 .623 & 1,25 & -92 \\
\hline \multicolumn{3}{|c|}{ Rata-rata } & 6,35 & 41,4 \\
\hline
\end{tabular}

Sumber : Data diolah

Tahun 2012 Return On Invesment /ROI KUD yang diperoleh dari hasil perbandingan antara laba setelah pajak sebesar Rp.69.010.440,- dengan total aktiva sebesar Rp.1.727.050.266,- adalah sebesar $4,00 \%$ atau 0,04 . Hal ini berarti total aktiva yang digunakan dalam usaha koperasi akan menghasilkan laba sebesar Rp.0,04.

Tahun 2013 Return On Invesment /ROI KUD yang diperoleh dari dari hasil perbandingan antara laba setelah pajak sebesar Rp.116.223.902,- dengan total 
aktiva sebesar Rp.1.554.070.512,- adalah sebesar 7,48\% atau 0,0748. Hal ini berarti total aktiva yang digunakan dalam usaha koperasi akan menghasilkan laba sebesar Rp.0,0748. Kondisi peningkatan ini dipengaruhi oleh meningkatnya jumlah laba yang dihasilkan serta menurunnya total aktiva pada komponen aktiva lancar berupa kas, piutang anggota, dan piutang lain-lain.

Tahun 2014 Return On Invesment /ROI KUD yang diperoleh dari hasil perbandingan antara laba setelah pajak sebesar Rp.217.870.502,- dengan total aktiva sebesar Rp.5.226.297.419,- adalah sebesar $4,17 \%$ atau 0,0417 . Hal ini total aktiva yang digunakan dalam usaha koperasi akan menghasilkan laba sebesar Rp.0,0417. Kondisi penurunan ini dipengaruhi oleh meningkatnya jumlah laba yang dihasilkan serta meningkatnya total aktiva pada komponen aktiva lancar berupa kas, bank, piutang anggota, piutang lain-lain dan persedian barang dan total aktiva pada komponen aktiva tetap berupa bangunan.

Tahun 2015 Return On Invesment /ROI KUD yang diperoleh dari hasil perbandingan antara laba setelah pajak sebesar Rp.411.809.443,- dengan total aktiva sebesar Rp.2.770.730.370,- adalah sebesar $14,86 \%$ atau 0,1486 . Hal ini berarti total aktiva yang digunakan dalam usaha koperasi akan menghasilkan laba sebesar Rp.0,1486,-. Kondisi peningkatan ini dipengaruhi oleh meningkatnya jumlah laba yang dihasilkan serta menurunnya total aktiva pada komponen aktiva lancar berupa kas dan bank dan meningkatnya total aktiva pada komponen aktiva tetap berupa bangunan, kendaraan \& mesin, peralatan, inventaris dan akumulasi penyusutan.

Tahun 2016 Return On Invesment /ROI KUD yang diperoleh dari hasil perbandingan antara laba setelah pajak sebesar Rp.47.530.732,- dengan total aktiva sebesar Rp.3.794.796.623,- adalah sebesar $1,25 \%$ atau 0,0125 . Hal ini berarti total aktiva yang digunakan dalam usaha koperasi akan menghasilkan laba sebesar Rp.0,0125. Kondisi penurunan ini dipengaruhi oleh menurunnya jumlah laba yang dihasilkan serta meningkatnya total aktiva pada komponen aktiva lancar berupa kas, bank, piutang anggota dan piutang lain-lain dan total aktiva pada komponen aktiva tetap berupa bangunan, kendaraan $\&$ mesin dan inventaris.

Melihat perkembangan berdasarkan hasil analisis rata-rata ROI KUD Barokah pada tahun 2012 sampai 2016 yaitu sebesar $6,35 \%$ atau 0,0635 . Artinya ROI rata-rata yang dihasilkan adalah sebesar Rp.0,0635 belum memenuhi standar yang ditetapkan. Hal ini menunjukkan KUD Barokah belum mampu mengelola total aktiva untuk menghasilkan SHU atau laba setelah pajak sebesar $>10 \%$.

\section{Return On Equity/ROE}

Rasio ini digunakan untuk mengetahui kemampuan perusahaan dalam meningkatkan SHU melalui penggunaan seluruh modal sendiri.

Tabel: 7. Hasil perhitungan rasio Return On Equity /ROE KUD Barokah Kecamatan Maro Sebo Ilir Tahun 2012 - 2016.

\begin{tabular}{|c|c|c|c|c|}
\hline \multirow[t]{2}{*}{ Tahun } & $\begin{array}{c}\text { Laba Setelah } \\
\text { Pajak }\end{array}$ & $\begin{array}{l}\text { Total Modal } \\
\text { Sendiri }\end{array}$ & ROE & Perkembangan \\
\hline & (Rp) & (Rp) & $(\%)$ & $(\%)$ \\
\hline 2012 & 69.010 .440 & 394.971 .690 & 17,47 & - \\
\hline 2013 & 116.223 .902 & 496.337 .761 & 23,42 & 34 \\
\hline 2014 & 217.870 .502 & 697.765 .338 & 31,22 & 33 \\
\hline 2015 & 411.809 .443 & 1.019 .971 .904 & 40,37 & 29 \\
\hline 2016 & 47.530 .732 & 817.785 .819 & 5,81 & -86 \\
\hline \multicolumn{3}{|c|}{ Rata-rata } & 23,66 & 2 \\
\hline
\end{tabular}

Sumber : Data diolah

Tahun 2012 Return On Equity /ROE KUD yang diperoleh dari hasil perbandingan antara laba setelah pajak sebesar Rp.69.010.440,- dengan total modal sendiri sebesar Rp.394.971.690,adalah sebesar $17,47 \%$ atau 0,1747 . Hal ini berarti modal sendiri yang digunakan dalam usaha koperasi akan menghasilkan laba sebesar Rp.0,1747.

Tahun 2013 Return On Equity/ROE KUD yang diperoleh dari dari hasil 
perbandingan antara laba setelah pajak sebesar Rp.116.223.902,- dengan total modal sendiri sebesar Rp.496.337.761,adalah sebesar $23,42 \%$ atau 0,2342 . Hal ini berarti modal sendiri yang digunakan dalam usaha koperasi akan menghasilkan laba sebesar Rp.0,2342. Kondisi ini mengalami peningkatan yang dipengaruhi oleh meningkatnya jumlah laba yang dihasilkan dan meningkatnya jumlah modal sendiri berupa simpanan wajib dan cadangan koperasi.

Tahun 2014 Return On Equity /ROE KUD yang diperoleh dari hasil perbandingan antara laba setelah pajak sebesar Rp.217.870.502,- dengan total modal sendiri sebesar Rp.697.765.338,adalah sebesar $31,22 \%$ atau 0,3122 . Hal ini berarti modal sendiri yang digunakan dalam usaha koperasi akan menghasilkan laba sebesar Rp.0,3122. Kondisi peningkatan ini dipengaruhi oleh meningkatnya laba yang dihasilkan dan meningkatnya jumlah modal sendiri berupa simpanan wajib dan cadangan koperasi.

Tahun 2015 Return On Equity /ROE KUD yang diperoleh dari hasil perbandingan antara laba setelah pajak sebesar Rp.411.809.443,- dengan total modal sendiri sebesar Rp.1.019.971.904,-adalah sebesar $-40,37 \%$ atau 0,4037. Hal ini berarti modal sendiri yang digunakan dalam usaha koperasi akan menghasilkan laba sebesar Rp.0,4037,-. Kondisi peningkatan ini dipengaruhi oleh meningkatnya laba yang dihasilkan dan meningkatnya jumlah modal sendiri berupa simpanan wajib dan cadangan koperasi.

Tahun 2016 Return On Equity /ROE KUD yang diperoleh dari hasil perbandingan antara laba setelah pajak sebesar Rp.47.530.732,- dengan total aktiva sebesar Rp.817.785.819,- adalah sebesar $5,81 \%$ atau 0,0581 . Hal ini berarti modal sendiri yang digunakan dalam usaha koperasi akan menghasilkan laba sebesar Rp.0,0581. Kondisi penurunan ini dipengaruhi oleh menurunnya laba yang dihasilkan dan menurunnya jumlah modal sendiri.

ROE terbesar dicapai pada tahun 2015 yaitu sebesar $40,37 \%>21 \%$. ROE terendah terjadi pada tahun 2016 yaitu sebesar 5,81\%. Melihat perkembangan berdasarkan hasil analisis rata-rata dari tahun 2012 sampai 2016 adalah sebesar $23,66 \%$ yang menunjukkan bahwa modal sendiri yang digunakan dalam usaha koperasi akan menghasilkan laba sebesar $23,66 \%$ atau 0,2366 artinya $\mathrm{ROE}$ rata-rata yang dihasilkan adalah sebesar Rp.0,2366 sudah memenuhi standar yang ditetapkan. Hal ini menunjukkan selama 5 tahun tersebut KUD Barokah mampu mengelola total modal sendiri untuk menghasilkan SHU atau laba setelah pajak sebesar > $21 \%$.

\section{SIMPULAN}

Dari perhitungan EVA dapat diperoleh informasi bahwa Koperasi mempunyai nilai tambah ekonomis yang dapat dikatakan cukup baik, hal ini menjadi nilai plus bagi Koperasi, karena belum tentu dengan SHU yang tinggi memiliki nilai tambah ekonomis sehingga tujuan Koperasi kurang maksimal Nilai EVA cenderung fluktuatif karena terjadi penurunan pada tahun 2016.

EVA membantu perusahaan dalam menghitung nilai tambah ekonomis, dimana nilai tambah ini ditujukan pada stakeholder. Dengan adanya nilai tambah, maka perusahaan dapat dikatagorikan sebagai perusahaan yang mempunyai reputasi yang bagus. Hal ini merupakan tantangan bagi Koperasi untuk meningkatkan EVA setiap tahunnya.

Pengukuran Kinerja keuangan suatu perusahaan dapat dilakukan dengan perhitungan Rasio Keuangan. Rasio yang digunakan dalam penelitian ini adalah Ratio Profitabilitas yaitu ROI dan ROE. Secara keseluruhan dengan menggunakan rasio keuangan dapat diperoleh informasi bahwa kinerja keuangan Koperasi mengalami fluktuasi selama lima tahun. 
Hal ini disebabkan karena jumlah hutang lancar lebih besar di bandingkan jumlah dari aktiva lancar.

\section{DAFTAR PUSTAKA}

Fahmi,Irham.2011.Analisis Kinerja Keuangan : Panduan Bagi Akademisi,

Manajer dan Investor untuk Menilai dan Menganalisa Bisnis dari Aspek Keuangan.Cetakan

Kesatu.Bndung : ALFABETA

Harahap, Sofyan Syafri. (2011:304). Analisis Kritis Atas Laporan Keuangan, Edisi ke 1 - 7. Jakarta : PT Raja Grafindo Persada.

Kamaludin. 2011. Manajemen Keuangan. CV Mandar Maju, Bandung.

Kasmir 2012. Analisis Laporan Keuangan. Jakarta : PT Raja Grafindo Persada.

Kasmir.2013. Analisis Laporan Keuangan. Jakarta: Rajawali Pers.

Kartikasari Anggara Fitria 2014, Analisis kinerja keuangan berbasis Economic Value Added pada perusahaan sektor industri otomotif di bursa efek Indonesia periode 2009-2013

Lee ,Oey Liang ,Appley A.Lawrence.2010. Pengantar Manajemen. Jakarta:

Salemba Empat.

Munawir. 2010. Analisis Laporan Keuangan. Yogyakarta : Liberty

O'Byrne, S., (2010). EVA and Market Value. Journal of Applied Corporate Finance 9. Pg 116-125.

Riyanto, Bambang. 2010. Dasar-dasar Pembelanjaan Perusahaan.

Yogyakarta:

Penerbit GPFE.

Sadeli, Lili M. 2011. Dasar-dasar Akuntansi. Bumi Aksara, Jakarta.

Stewart, G.B.,III., (1991), The Quest for Value: The EVA Management Guide, New York, Harper Business.
Teuku, Mirza. 2010. EVA sebagai Alat Penilai, Usahawan No. 04 Tahun XXIV 68. Jakarta.

Tunggal, Amin Widjaya. (2010), Memahami Konsep Value Added (EVA) dan Value Base Management (VBM), Harvarindo, Jakarta.

Utama, Siddharta, (2010 : 10). Economic Value Added : Pengukur Penciptaan Nilai Perusahaan, Usahawan No. 04 Tahun XXVI. Jakarta

Van Hone,James C.dan Jhon M.2010.Prinsip-prinsip Manajemen Keuangan.

Edisi 12. Jakarta : Salemba Empat.

Young, S. David and Stephen F. O'Byrne, (2001). EVA and Value-Based Management: A Practical Guide to Implementation, New York, Mc Graw-Hill. 